\title{
SYNDEMIC INTERACTION BETWEEN HIV AND TB- A CATASTROPHIC DUET
}

\author{
Ivneet Kour ${ }^{1}$, Ramandeep Kaur², Dhruvendra Lal ${ }^{3}$, Sumit Kapoor ${ }^{4}$, Gursimran Singh ${ }^{5}$
}

1Postgraduate Student, Department of Microbiology, Adesh Institute of Medical Sciences and Research, Bathinda, Punjab.

2Resident, Soni Hospital, Jaipur, Rajasthan.

3Postgraduate Student, Department of Community Medicine, Adesh Institute of Medical Sciences and Research, Bathinda, Punjab.

${ }^{4}$ Resident, Soni Hospital, Jaipur, Rajasthan.

${ }^{5}$ Consultant, Apollo Clinics, Chandigarh, Punjab.

\begin{abstract}
BACKGROUND
ABSTRACT

TB is the most common opportunistic infection (OI) among HIV-infected individuals and co-infected individuals are at high risk of death. The risk of developing tuberculosis (TB) is estimated to be between 16 - 27 times greater in people living with HIV than among those without HIV infection. In 2015, there were an estimated 10.4 million cases of tuberculosis disease globally including 1.2 million (11\%) among people living with HIV.

Aims and Objectives- To study the distribution between demographic profile and HIV-TB co-infection and to study the clinical profile of patients with HIV-TB co-infection.
\end{abstract}

\section{MATERIALS AND METHODS}

A hospital-based observational study was conducted on 150 patients of HIV-TB co-infection coming to Department of Medicine/ ART Centre in Rajindra Hospital, Patiala.

\section{RESULTS}

A total of 150 patients were included in this study. Prevalence was more among unemployed and illiterate people.

\section{CONCLUSION}

This study showed that there were significant associations between various risk factors, demographic factors and HIV-TB coinfection.

\section{KEYWORDS}

HIV/ AIDS, Tuberculosis, Co-Infection, CD4 Cell Count, Prevalence, Symptoms.

HOW TO CITE THIS ARTICLE: Kour I, Kaur R, Lal D, et al. Syndemic interaction between HIV and TB- a catastrophic duet. J. Evolution Med. Dent. Sci. 2018;7(15):1829-1832, DOI: 10.14260/jemds/2018/413

\section{BACKGROUND}

A syndemic is defined as the aggregation of two or more diseases that act synergistically to magnify the burden of disease. The syndemic interaction between the human immunodeficiency virus (HIV) and tuberculosis (TB) epidemics has had drastic consequences around the globe. TB is the most common opportunistic infection (OI) among HIVinfected individuals and co-infected individuals are at high risk of death. ${ }^{1}$ World Health Organisation (WHO) indicated that there is an estimated 1.3 million TB deaths among HIVnegative people (down from 1.7 million in 2000) in the past year and an additional 374,000 deaths among HIV-positive people. ${ }^{2}$ Global burden of HIV/AIDS is about 36.7 million. ${ }^{3}$ The risk of developing tuberculosis (TB) is estimated to be between 16 - 27 times greater in people living with HIV than among those without HIV infection. In 2015, there were an estimated 10.4 million cases of tuberculosis disease globally including 1.2 million (11\%) among people living with HIV.

'Financial or Other Competing Interest': None.

Submission 22-02-2018, Peer Review 21-03-2018,

Acceptance 28-03-2018, Published 09-04-2018.

Corresponding Author:

Dr. Dhruvendra Lal,

Department of Community Medicine,

Adesh Institute of Medical Sciences and Research,

Bathinda, Punjab.

E-mail:drdhruvlal@gmail.com

DOI: $10.14260 /$ jemds $/ 2018 / 413$

\section{(c) $(\$) \ominus$}

Almost $60 \%$ (57\%) of tuberculosis cases among people living with HIV were not diagnosed or treated, resulting in 390,000 tuberculosis-related deaths among people living with HIV. WHO global tuberculosis report 2014 reveals that there were 1.2 million co-infected individuals in India at the end of 2013 and the mortality due to TB-HIV is significant, amounting to 38,000 cases. ${ }^{2,3}$

Individuals with HIV infection are at increased risk for tuberculosis (TB). The altered CD4 T-cell homeostasis induced by HIV infection may play a key role in the development of tuberculosis in HIV-infected patients. ${ }^{4}$ In the individual host, the two pathogens M. tuberculosis and HIV potentiate one another, accelerating the deterioration of immunological functions and resulting in premature death if untreated. Some 14 million individuals worldwide are estimated to be dually infected. TB is the largest single cause of death in the setting of AIDS, accounting for about $26 \%$ of AIDS-related deaths. ${ }^{5}$ HIV co-infection is the most powerful known risk factor for progression of $\mathrm{M}$. tuberculosis infection to active disease, increasing the risk of latent $\mathrm{TB}$ reactivation 20 -fold. Likewise, TB has been reported to exacerbate HIV infection. $6,7,8$

The problem is now further complicated by relentless spread of HIV, which causes AIDS pandemic and emergence of MDR-TB. HIV further fuels the disease in people infected with $\mathrm{TB}$, accounting for $5 \%$ to $15 \%$ of risk of developing active tuberculosis. The potentiating effect between HIV and TB is well established in studies from Africa and evidence is gradually mounting in the Asian and Pacific regions as well. 
Rapid spread of HIV could lead to increasing burden of TB. India bears the burden of 2.5 million people infected with HIV. Of these, $40 \%$ suffer co-infection with TB. ${ }^{9,10}$ Considering the fact that about a third of world's population is infected with Mycobacterium tuberculosis, more than half of which lives in countries ravaged by HIV/ AIDS, thus the gravity of present situation becomes evident. Overall, this syndemic disease has taken the form of major health catastrophe. It directly or indirectly increases the cost of illness, has a socioeconomic stigma and affects the quality of life of individuals. Thus, it would be rightly described as "cursed duet." This is also evident from TB-HIV co-infection incidence data for the year 2016 in South East Asia Region, which was 12 per 100,000 with mortality of 3.9 per $100,000.11$

The road ahead is complex, but one that must be traversed with the best evidence available and a willingness to take brave and decisive action to reverse the lost ground and to make critical gains to control both HIV and TB.

\section{Aims and Objectives}

- To study the distribution between demographic profile and HIV-TB co-infection.

- To study the clinical profile of patients with HIV-TB coinfection.

\section{MATERIALS AND METHODS}

This is a hospital-based observational study, which was conducted at Rajindra Hospital, Patiala. The study was conducted on 150 patients of HIV-TB co-infection coming to Department of Medicine/ ART centre in Rajindra Hospital, Patiala. The patients were selected for the study from-

1. ART Centre, Rajindra Hospital, Patiala.

2. Patient diagnosed as HIV-TB co-infection while being treated in Rajindra Hospital, Patiala (indoor/outdoor).

\section{Inclusion Criteria}

Diagnosed patient of HIV-TB co-infection.

\section{Exclusion Criteria}

Patients with only TB or HIV/ AIDS and patients not willing to participate in the study.

Research and Ethical clearance was obtained, after which the study was initiated. The details of all the participants in this study was kept confidential. Detailed history of the patients include age, marital status, status of the spouse, clinical features (fever, cough, weight loss, haemoptysis and other symptoms as per proforma). A general systemic examination was also conducted, which included both clinical examination and routine blood examination. Sputum microscopy was performed at DOTS centre, Rajindra Hospital, Patiala.

Relevant statistical tests were applied using MS Excel and Open Epi software.

\section{RESULTS}

A total of 150 patients were included in this study. Table 1 shows the demographic details of all the patients. Majority of the patients were in the age group of 31 to 40 years and $74 \%$ of the participants belonged to rural area and only $26.8 \%$ were from urban sector. Two male patients had weight of 28 $\mathrm{kg}$ and $22 \mathrm{~kg}$ (not included in Table 1). $80 \%$ of participants were married, $16 \%$ were unmarried and $4 \%$ were widow (all females). 24 patients were unmarried, hence not mentioned in Table 1.

Figure 1 shows the occupational status of all the participants. Unemployed along with others constituted the biggest group comprising $30.1 \%$. Drivers alone constituted $25 \%$ of the population. Figure 2 shows the education of all the participants. $12.6 \%$ (19 out of 150 ) were illiterate. Figure 3 shows the route of transmission and it was found that sexual route was the commonest $(91.33 \%)$, whereas blood transfusion was responsible for $4.67 \%$ of cases.

Table 2 shows the distribution of gender and presenting symptoms with CD4 count of the patients.

\begin{tabular}{|c|c|c|c|c|c|c|c|}
\hline Variable & \multicolumn{2}{|c|}{ Male } & \multicolumn{2}{|c|}{ Female } & \multicolumn{2}{|c|}{ Total } & P value \\
\hline Age (yrs.) & $\mathbf{N}$ & $\begin{array}{c}\% \\
\text { Age }\end{array}$ & $\mathbf{N}$ & $\begin{array}{c}\% \\
\text { Age } \\
\end{array}$ & $\mathbf{N}$ & $\begin{array}{c}\% \\
\text { Age }\end{array}$ & \multirow{5}{*}{0.003844} \\
\hline $21-30$ & 21 & 14 & 11 & 7.3 & 32 & 21.3 & \\
\hline $31-40$ & 68 & 45.4 & 12 & 8 & 80 & 53.4 & \\
\hline $41-50$ & 24 & 16 & - & - & 24 & 16 & \\
\hline $51-60$ & 5 & 3.3 & - & - & 5 & 3.3 & \\
\hline \multicolumn{8}{|l|}{\begin{tabular}{|l|} 
Residence \\
\end{tabular}} \\
\hline Rural & 87 & 58 & 24 & 16 & 111 & 74 & \multirow{2}{*}{$\begin{array}{c}0.03618 \\
\text { (with } \\
\text { correction) }\end{array}$} \\
\hline Urban & 37 & 24.6 & 2 & 1.3 & 39 & 26 & \\
\hline \multicolumn{8}{|l|}{$\begin{array}{c}\text { Weight } \\
\text { (kg) }\end{array}$} \\
\hline $30-40$ & 19 & 12.6 & 13 & 8.9 & 32 & 21.4 & \multirow{4}{*}{$<0.001$} \\
\hline $41-50$ & 36 & 24 & 10 & 7.1 & 46 & 30.6 & \\
\hline 51-60 & 40 & 26.6 & 3 & 1.8 & 43 & 28.6 & \\
\hline$>60$ & 27 & 18 & - & - & 27 & 18 & \\
\hline \multicolumn{8}{|l|}{$\begin{array}{l}\text { Marital } \\
\text { Status }\end{array}$} \\
\hline Married & 100 & 66.7 & 20 & 13.3 & 120 & 80 & \multirow{3}{*}{$<0.001$} \\
\hline Unmarried & 24 & 16 & - & - & 24 & 16 & \\
\hline Widow & - & - & 6 & 4 & 6 & 4 & \\
\hline \multicolumn{8}{|l|}{$\begin{array}{l}\text { HIV status } \\
\text { of spouse }\end{array}$} \\
\hline HIV +ve & 74 & 49.3 & 16 & 10.7 & 90 & 60 & \multirow{3}{*}{0.4262} \\
\hline HIV -ve & 22 & 14.7 & 8 & 5.3 & 30 & 20 & \\
\hline Unknown & 4 & 2.7 & 2 & 1.3 & 6 & 4 & \\
\hline
\end{tabular}

Table 1. Demographic Details of All Participants

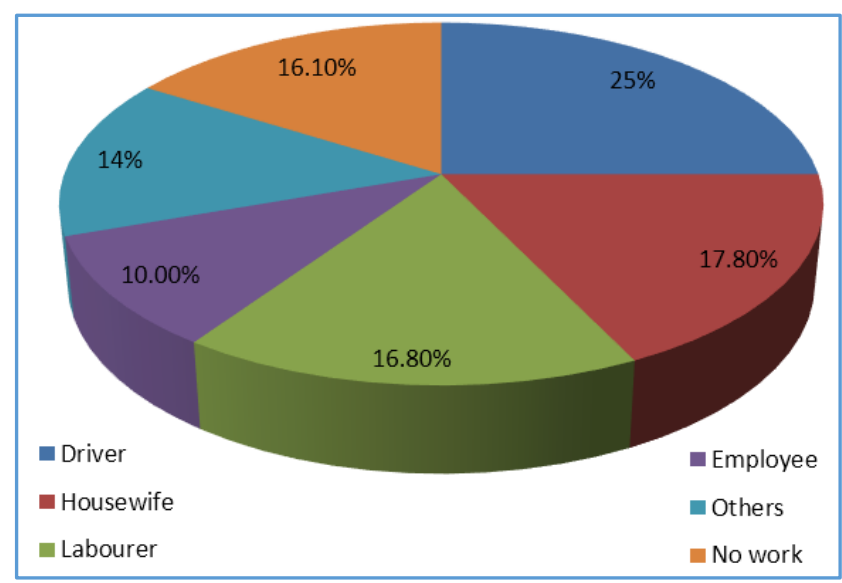

Figure 1. Occupational Status of All Participants 


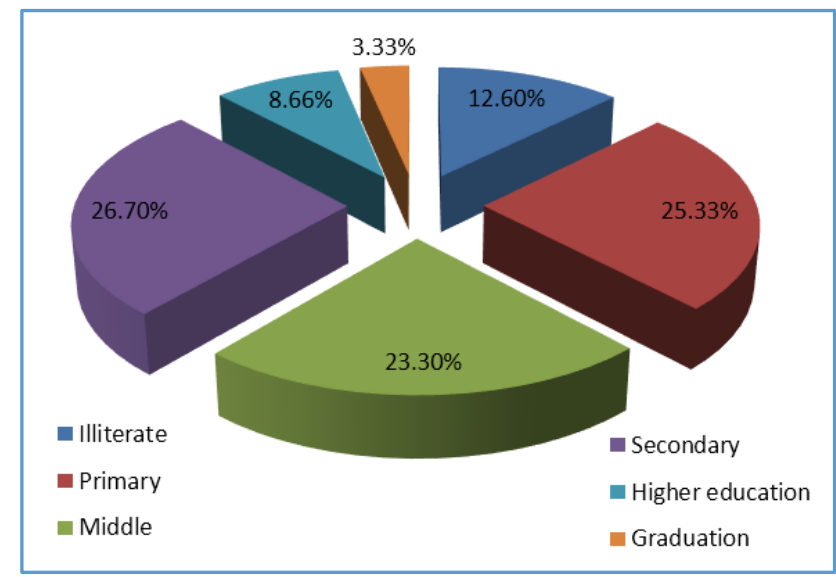

Figure 2. Education of All Participants

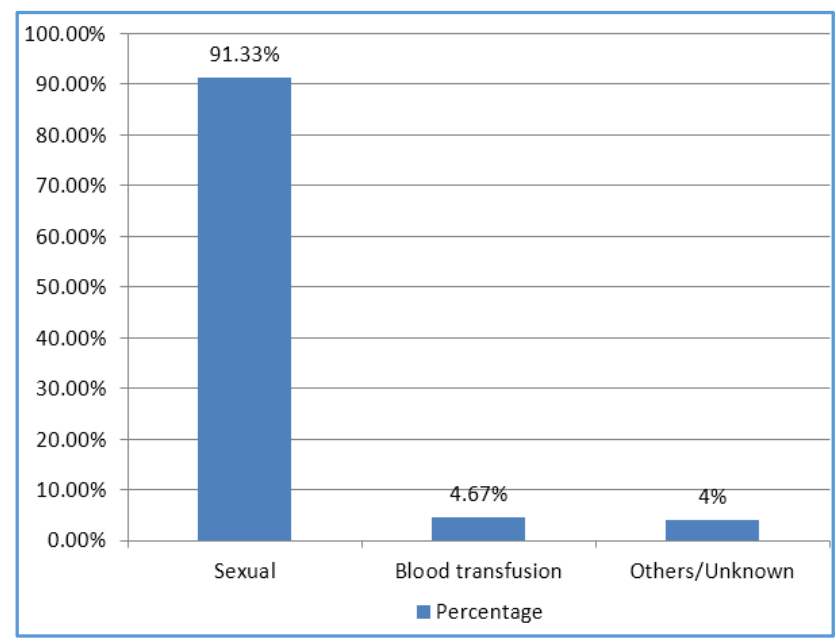

Figure 3. Route of Transmission

\begin{tabular}{|c|c|c|c|c|c|}
\hline Variable & \multicolumn{4}{|c|}{ CD4 Count (per microL) } & \multirow{2}{*}{$P$ value } \\
\hline & $<100$ & $100-200$ & $201-300$ & $>300$ & \\
\hline \multicolumn{6}{|l|}{ Gender } \\
\hline Male & $\begin{array}{c}71 \\
(41.33 \%)\end{array}$ & $\begin{array}{c}39 \\
(26 \%)\end{array}$ & $\begin{array}{c}5 \\
(3.3 \%)\end{array}$ & $\begin{array}{c}9 \\
(6 \%)\end{array}$ & \multirow{2}{*}{0.02278} \\
\hline Female & $\begin{array}{c}10 \\
(6.67 \%) \\
\end{array}$ & $\begin{array}{c}10 \\
(6.67 \%) \\
\end{array}$ & \begin{tabular}{|c|}
5 \\
$(3.33 \%)$ \\
\end{tabular} & $\begin{array}{c}1 \\
(0.67 \%) \\
\end{array}$ & \\
\hline Total & $\begin{array}{c}81 \\
(54 \%)\end{array}$ & $\begin{array}{c}49 \\
(32.67 \%)\end{array}$ & $\begin{array}{c}10 \\
(6.67 \% \\
\end{array}$ & $\begin{array}{c}10 \\
(6.66 \%)\end{array}$ & \\
\hline \multicolumn{6}{|l|}{$\begin{array}{c}\text { Clinical } \\
\text { Symptoms }\end{array}$} \\
\hline Fever & $\begin{array}{c}9 \\
(11.11 \%) \\
\end{array}$ & $\begin{array}{c}22 \\
(44.89 \%) \\
\end{array}$ & $3(30 \%)$ & $6(60 \%)$ & \multirow{4}{*}{$<0.001$} \\
\hline Cough & \begin{tabular}{|c|}
54 \\
$(66.67 \%)$ \\
\end{tabular} & $4(8.16 \%)$ & $2(20 \%)$ & $5(50 \%)$ & \\
\hline Wt. Loss & $\begin{array}{c}31 \\
(38.2 \%)\end{array}$ & $\begin{array}{c}19 \\
(38.7 \%)\end{array}$ & $2(20 \%)$ & $3(30 \%)$ & \\
\hline $\begin{array}{l}\text { Haemo- } \\
\text { ptysis }\end{array}$ & $3(3.7 \%)$ & $1(1.23 \%)$ & $2(20 \%)$ & - & \\
\hline
\end{tabular}

\section{DISCUSSION}

The present study was conducted in Department of Medicine at Rajindra Hospital, Patiala. Participants were 150 cases of HIV-TB co-infection taken from ART centre, OPD and wards. The cases were selected after satisfying all the exclusion and inclusion criterion. All the relevant details including history and investigations were done and then further analysed.

Out of total cases (150), there were $26(17.33 \%)$ females and $124(82.66 \%)$ males. In this study, majority of the patients with HIV-TB co-infection were in the age group of 31-40 years (53.6\%). This finding was compatible with a study done by Dasilva et al, which stated that the mean age of 87 HIV-TB co-infected patients between $34+8$ years. ${ }^{12}$ Studies conducted by Aerts and Jobin ${ }^{13}$ and Liberato et al ${ }^{14}$ showed a male preponderance, which further supports this study.

The progression of both HIV and TB depends on several factors such as environment, nutrition, health status, economic status and education. Hochedez et al found that HIV-TB co-infection was more common in patients living in rural set-up. 15 This study also showed that rural population $(74 \%)$ is more affected with this co-infection and rural women are more frequently affected than their urban counterparts (1.33\%). Lack of awareness and ignorance is one of the most important factors that accounts for rural urban difference. Therefore, increased awareness needs to be created more in rural areas about HIV/ AIDS and opportunistic infections to control rapid spread of this disease in vulnerable population.

Social makeup of the patients was favourable. Majority of the participants were drivers $(25 \%)$ followed by housewives (17.8\%), labourers (16.8\%), employees (10\%), unemployed (16.1\%) and others (21\%). High prevalence of HIV-TB coinfection in drivers may be due to increased risk of high-risk behaviour. Further poor knowledge about safe sexual practices worsens the existing scenario. It has been noted that drivers had a poor compliance to HIV treatment, probably because of nature of work. Hence, they are at increased risk of opportunistic infections as well. Similar study done by Erokhin et al showed the prevalence of TB-HIV co-infection of $5 \%$ in employed and $50 \%$ in unemployed population. ${ }^{16}$

Low literacy level is a risk factor for HIV-TB co-infection. Most of the patients were unaware of the importance of safe sex, clean surrounding and proper nutrition. This study showed that $48.3 \%$ of patients had up to 8 years of schooling, while $12.5 \%$ were illiterates. Similar findings were reported by Aerts and Jobin who also stated that HIV-TB co-infection is more prevalent in patients less than 8 years of schooling.

Heterosexual is the commonest mode of transmission of HIV infection according to Song et al. ${ }^{17}$ The present study also depicted that heterosexual route was the most common route of transmission (91.33\%) followed by blood transfusion (4.66\%).

A total of $54 \%$ (including $47.33 \%$ males and $6.67 \%$ females) had CD4 count below 100/ microL $6.67 \%$ patients had CD4 count between 201 - 300/ microL and more than 300/ microL. At higher CD4 cell counts, fever followed by cough and weight loss were the commonest presenting symptoms. With declining CD4 cell count, cough is the commonest presenting symptom followed by weight loss. Kumar et al reported fever as the most common (87\%) followed by cough (75\%) and weight loss (71\%). This study also showed fever as the commonest $(96.4 \%)$ followed by cough $(60.7 \%)$ and weight loss (78.6\%) presenting symptoms in HIV-TB co-infection. 


\section{CONCLUSION}

Majority of the population was in the age group of $31-40$ years with higher number of cases from rural sector. Unemployment and poor literacy was associated with this coinfection. Heterosexual route was the commonest and fever, weight loss, cough and haemoptysis were the presenting symptoms of the patients.

Thus, role of health education, IEC and BCC activities and counselling at the community as well as all health care centres plays an important role in curbing the menace of this lethal symbiosis of HIV and TB.

\section{REFERENCES}

[1] Corbett E, Watt CJ, Walker N, et al. The growing burden of tuberculosis: global trends and interactions with the HIV epidemic. Arch Intern Med 2003;163(9):1009-21.

[2] Global tuberculosis report. World Health Organization. 2018.

http://www.who.int/tb/publications/global_report/e n

[3] World Health 2018. http://www.who.int/hiv/en/

[4] Vajpayee M, Kanswal S, Seth P, et al. Tuberculosis infection in HIV-infected Indian patients. AIDS Patient Care STDS 2004;18(4):209-13.

[5] Getahun H, Gunneberg C, Granich R, et al. HIV infection-associated tuberculosis: the epidemiology and the response.Clin Infect Dis 2010;50(Suppl 3):S201-S7.

[6] Selwyn PA, Hartel D, Lewis VA, et al. A prospective study of the risk of tuberculosis among intravenous drug users with human immunodeficiency virus infection. N Engl J Med 1989;320(9):545-50.

[7] Whalen C, Horsburgh CR, Hom D, et al. Accelerated course of human immunodeficiency virus infection after tuberculosis. Am J Respir Crit Care Med 1995;151(1):129-35.
[8] Modjarrad K, Vermund SH. Effect of treating coinfections on HIV-1 viral load: a systematic review. Lancet Infect Dis 2010;10(7):455-63.

[9] Marfatia YS, Sharma A, Modi M. Overview of HIV/AIDS in India. Indian J Sex Transm Dis \& AIDS 2007;28(1):15.

[10] Sharma SK, Mohan A. Co-infection of Human Immunodeficiency Virus (HIV) and tuberculosis: Indian perspective. Indian J Tuberc 2004;51:5-16.

[11] Tiberi S, Carvalho A, Sulis G, et al. The cursed duet today: Tuberculosis and HIV-coinfection. Presse Méd 2017;46(2 Pt 2):e23-e39.

[12] Da Silva RM, da Rosa L, Lemos RN. Radgraphic alteration in patients with human immunodeficiency virus/ tuberculosis co-infection: correlation with CD4+ T cell counts. J Bras Pneumol 2006;32(3):22833.

[13] Aerts D, Jobim R. The epidemiological profile of tuberculosis in southern Brazil in times of AIDS. Int J Tuberc Lung Dis 2004;8(6):785-91.

[14] Liberato IR, de Albuquerque ME, Campelo AR, et al. Characteristics of pulmonary tuberculosis in HIV seropositive and sero-negative patients in Northeastern region of Brazil. Rev Soc Bras Med Trop 2004;37(1):46-50.

[15] Hochedez P, Zeller V, Truffot C, et al. Lymph-node tuberculosis in patients infected or not with HIV: general characteristics, clinical presentation, microbiological diagnosis and treatment. Pathol Biol (Paris) 2003;51(8-9)496-502.

[16] Erokhin VV, Kornilova ZKH, Alekseeva LP. The specific features of the detection, clinical manifestations and treatment of tuberculosis in the HIV infected. Probl Tuberk Bolezn Legk 2005;(10):20-8.

[17] Song AT, Schout D, Novaes HM, et al. Clinical and epidemiological features of AIDS/Tuberculosis co morbidity. Res Hosp Clin Fac Med Sao Paulo 2003;58(4):207-14. 